\title{
Gambaran Kebutuhan Psikologis Anak Berbakat
}

Tyesa Sri Handayuni

Bimbingan dan Konseling, Universitas Negeri Padang, Sumatera Barat.

Indonesia tyesasri@gmail.com

\begin{abstract}
Tiap peserta didik mempunyai berbagai macam dorongan kebutuhan termasuk siswa berbakat baik yang bersifat kejasmanian, sosial, maupun kejiwaan. Pada prinsipnya dorongan kebutuhan ini menuntut untuk dipenuhi. Dengan kata lain dorongan kebutuhan ini akan mendasari tingkah peserta didik serta kelangsungan hidup pese ta didik. Bila dorongan kebutuhan peserta didik itu dapat terpenuhi, peserta didik akan merasakan kepuasan serta kebahagiaan dalam hidupnya, dan sebaliknya.
\end{abstract}

\section{Keywords:}

Article History: Received on 17/09/2017; Revised on 17/10/2017; Accepted on 17/11/2017; Published Online: 20/11/2017.

This is an open access article distributed under the Creative Commons Attribution License, which permits unrestricted use,
distribution, and reproduction in any medium, provided the original work is properly cited. (c) 2019 by author.

Banyak anak-anak berbakat tidak menerima layanan pendidikan yang sesuai untuk mereka. Dengan mengabaikan untuk memberi mereka pendidikan yang layak yang harus diterima, akan membuat anak-anak berbakat tidak dapat tumbuh dan berkembang aspek bakat mereka.Secara yuridis formal layanan pendidikan bagi anak berbakat telah mendapat tempat di dalam sistem pendidikan nasional. Undang-Undang Sistem Pendidikan Nasional Pasal 5 Ayat 4 menyatakan bahwa "warga negara yang memiliki potensi kecerdasan dan bakat istimewa berhak memperoleh pendidikan khusus". Di samping itu juga dalam Pasal 12 Ayat 1b dikatakan bahwa "setiap peserta didik pada setiap satuan pendidikan berhak mendapatkan pelayanan pendidikan sesuai dengan bakat, minat dan kemampuannya" (Larasati et al., n.d.).

Dalam sistem pendidikan nasional kita, dulu anak-anak yang termasuk dalam kualifikasi berbakat perlu mendapat "perhatian khusus" (UUSPN Tahun 1989), kini disebutkan berhak mendapat layanan "pendidikan khusus", sebagaimana dinyatakan dalam UU No. 20 Tahun 2003 Pasal (5) ayat (4) bahwa : "Warga negara yang memiliki potensi kecerdasan dan bakat istimewa berhak memperoleh pendidikan khusus". Selanjutnya dalam Pasal (12) ayat (1) poin (b) dan (f) dinyatakan bahwa : “Setiap peserta didik pada setiap satuan pendidikan berhak: mendapatkan layanan pendidikan sesuai bakat, minat, dan kemampuannya; serta menyelesaikan program pendidikan sesuai dengan kecepatan belajar masing-masing dan tidak menyimpang dari ketentuan batas waktu yang ditetapkan (dalam undang-undang ini digunakan istilah anak dengan potensi kecerdasan dan bakat istimewa yang pengertiannya sinonim dengan anak berbakat). 


\section{Keberbakatan}

Konsep keberbakatan dijelaskan oleh Monks mengajukan konsep "model Triadic bakat" sebagai model perbaikan untuk "Tiga-cincin Konsepsi bakat "yang diusulkan oleh Renzulli dengan menambahkan unsur keluarga, sekolah dan teman sebaya (lingkungan atau lingkungan), untuk melengkapi konsep Renzulli yang terdiri dari kreativitas, komitmen tugas, dan kemampuan atas rata-rata. Konsep biarawan mempertimbangkan pendidikan yang layak bagi anak-anak berbakat untuk mengembangkan bakat mereka, seperti kelas khusus, kelas akselerasi atau kelas pengayaan (Idrus, 2013). Kemudian menurut (Olimat, 2010) "The defenition of gifted student is the person who has high performance in one fielf or more sucg as general cognitivie abilities, leadership, discovery thinking, achievement abilities, pyscho movement abilities and social sklills "(Olimat, 2010).

Anak berbakat adalah individu unik dengan karakteristik dan kebutuhan tersendiri yang relatif berbeda dengan anak normal pada umumnya. Munculnya karakteristik dan kebutuhan khas pada anak berbakat tersebut di samping berdampak positif terhadap berbagai aspek perkembangan, di sisi lain cenderung melahirkan berbagai permasalahan psikologis, emosional, sosial, pribadi, akademik, maupun karir pada mereka. Berkaitan dengan karir, keberbakatan dengan segala permasalahannya berimplikasi kuat pada perlunya dirumuskan suatu model alternatif layanan bimbingan, khususnya bimbingan karir yang mampu mengakses keberbakatan dan permasalahan mereka, sehingga karir mereka dapat berkembang secara optimal. Dengan demikian mereka mengaktualisasikan keberbakatannya dan melalui karirnya yang mantap mereka dapat memberikan sumbangan besar bagi kemajuan bangsa. Dengan layanan karir yang tepat, minimal dengan kelebihannya mereka dapat menguasai karirnya dengan baik, dan bukannya kewalahan dalam menghadapinya (Karir, 2008)

\section{Ciri- ciri keberbakatan}

Menurut pandangan Renzulli dengan theree ring interacionnya, yaitu pandangan bahwa keberbakatan dicirikan dengan tiga hal, yaitu (1) pemilikian kemampuan intelektulal diatas rata-rata, (2) kreativitas (3) tas comitment Dikarenakan memberi arah yang lebih jelas dalam identifikasinya dan mampu membedakan mereka yang berbakat karena faktor motivasi atau kreativitas, sekalipun kurang fungsional dalam kepentingan pendidikan karena tidak mampu menjaring mereka yang secara potensial berbakat tetapi tidak kreatif atau task commitment-nya masih rendah (Karir, 2008).

\section{Kebutuhan Psikologis}

Tiap peserta didik sebagai individu mempunyai berbagai macam dorongan kebutuhan baik yang bersifat kejasmanian, sosial, maupun kejiwaan. Pada prinsipnya dorongan kebutuhan ini menuntut untuk dipenuhi. Dengan kata lain dorongan kebutuhan ini akan mendasari tingkah peserta didik serta kelangsungan hidup peser ta didik. Bila dorongan kebutuhan peserta didik itu dapat terpenuhi, peserta didik akan merasakan kepuasan serta kebahagiaan dalam hidupnya, dan sebaliknya (Hendrarno dkk, 2003) (Bk \& Pancasakti, 2015)

Peran guru bimbingan dan konseling dalam membimbing peserta didik untuk menemuk an kebutuhannya memang sangat besar, dapat dilihat dalam tujuan bimbingan dan konseling yaitu membantu peserta didik untuk mengembangkan 
potensi peserta didik secara optimal. Tujuan itu hampir sama dengan tujuan nasional yang tertera di atas. Akan tetapi s emua itu tidaklah mudah dalam membimbingnya, seperti halnya anak -anak yang kecerdasannya di bawah rata-rata itu juga perlu perhatian khusus apalagi anak -anak yang memiliki kebutuhan psikologis pastinya perlu perhatian khusus juga. Dari sinilah kita harus dapat mengerti apa sajakah yang dibutuhkan peserta didik di SMA Lab School, dan semuanya itu membutuhkan proses dalam mengerjakannya (Bk \& Pancasakti, 2015).

Sebagai mahluk psiko-fisik manusia memiliki kebutuhan-kebutuhan fisik dan psikologis, dan sebagai mahluk individu dan mahluk sosial, manusia mempunyai kebutuhan individu (yang juga dikenal sebagai kebutuhan pribadi) dan kebutuhan sosial kemasyarakatan. Dengan demikian, maka setiap individu tentu memiliki kebutuhan, karena ia tumbuh dan berkembang untuk mencapai kondisi fisik dan sosial psikologis yang lebih sempurna dalam kehidupannya (Sunarto, 1999) dalam (Bk \& Pancasakti, 2015).

Hal itu diharapkan agar para peserta didik dapat mendapatkan kebutuhankebutuhan mereka terutama kebutuhan psikologis mereka seiring dengan kegiatan yang dipilihnya dan dijalaninya. Manusia mempunyai kebutuhan-kebutuhan psikologis, yang harus diberi kepuasan, sebab kalau tidak, akan menimbulkan kesukaran-kesukaran. Kebutuhan $p($ Karir, 2008)is ini timbul dari suatu kenyataan, bahwa manusia itu mahluk sosial, yang berkembang dan hidup serta bekerjasama dengan orang lain. Dengan kebutuhan-kebutuhan biologis biasanya rangsangrangsang berasal dari tubuhnya sendiri, sedang dengan kebutuhan -kebutuhan psikologis rangsang-rangsang datang dari orang lain (Partowisastro 1983) dalam (Bk \& Pancasakti, 2015).

Dalam institusi pendidikan terutama di sekolah para peserta didik adalah sentral pokok terciptanya kondisi sekolahan yang baik. Di sini membuktikan bahwa betapa pentingnya pesert a didik di sekolah, dalam hal ini para guru harus mengetahui apa-apa saja yang menjadi kebutuhan peserta didiknya. Untuk itu harus ada pengidentifikasian kebutuhan peserta didik di sekolah, yang bertujuan agar para peserta didik dapat memperoleh apa yang m enjadi kebutuhannya pada saat ini. Dalam kaitannya dengan kebutuhan peserta didik yang harus diketahui oleh para guru dan dilaksanakan oleh masing-masing guru terutama oleh guru bimbingan dan konseling, maka proses identifikasi kebutuhan menjadi sangat penting. Proses identifikasi kebutuhan peserta didik menjadi tolak ukur terciptanya suatu proses pengajaran, yaitu agar proses belajar-mengajar dapat berjalan dengan baik (Karir, 2008).

Memang memiliki tantangan yang besar untuk mengetahui apa sajakah yang dibutuhkan untuk psikologis peserta didik, akan tetapi sekolah yang labelnya hanya sekolah swasta ini dapat menghasilkan para peserta didik yang memiliki kemampuan untuk bersaing dengan peserta didik lainya dan itu dikarenakan kebutuhan-kebutuhan psikologis yang didapat dalam proses belajar mengajar di sekolah tersebut. Untuk itu peneliti akan mencoba menggali informasi bagaimana proses pemenuhan kebutuhan psikologis peserta didik, karena para peserta didik harus dipenuhi kebutuhannya secara khusus agar mereka dapat mengembangkan 
potensi yang ada dalam dirinya(Psikologi, Kedokteran, \& Udayana, 2015).

Dalam proses pendidikan di sekolah, peserta didik sebagai subjek didik, merupakan pribadi pribadi yang unik dengan segala $\mathrm{k}$ arakteristiknya. Peserta didik sebagai individu yang dinamis dan berada dalam proses perkembangan, memiliki kebutuhan dan dinamika dalam interaksinya dengan lingkungannya. Sebagai pribadi yang unik, terdapat perbedaan individual antara peserta didik yang satu dengan peserta didik yang lainnya. Di samping itu, peserta didik sebagai pelajar, senantiasa terjadi adanya perubahan tingkah laku sebagai hasil proses belajar (Mugiarso, 2004 ) (Idrus, 2013).

\section{Teori Kebutuhan}

Selama proses perkembangan anak menjadi dewasa seutuhnya, terdapat kebutuhankebutuhan dasar atau keinginan anak untuk menjadi sesuatu (Gunarsa, 2008). Maslow (dalam Gunarsa, 2008) dalam (Psikologi et al., 2015) membagi kebutuhan dasar individu menjadi dua kelompok, yaitu kebutuhan primer atau kebutuhan fisologis seperti makan dan minum, serta kebutuhan sekunder atau kebutuhan psikologis seperti kebutuhan akan rasa aman. Kebutuhan primer atau fisiologis dan kebutuhan sekunder atau psikologis akan dapat terpenuhi dengan cara individu melakukan tindakan atau perilaku tertentu. Seperti misalnya untuk memenuhi kebutuhan fisiologis, ketika individu merasakan lapar, maka individu akan berperilaku tertentu untuk mendapatkan sesuatu yang bisa dimakan, sedangkan ketika individu membutuhkan rasa aman, maka individu akan berperilaku tertentu untuk memperoleh perasaan dicintai, diterima, didukung dan dihargai oleh lingkungan sekitar. Kebutuhan psikologis terkait kebutuhan akan rasa aman tersebut merupakan kebutuhan yang sangat penting dipenuhi pada masa perkembangan anak setelah kebutuhan primer atau kebutuhan fisiologis terpenuhi, kerena pemenuhan kebutuhan rasa aman tersebut akan mempengaruhi perkembangan psikologis anak baik dari segi emosi, mental maupun kepribadian. Ketika anak berhasil memenuhi kebutuhan psikologis, maka anak akan matang secara emosi dan perilaku dimana kematangan emosi dan perilaku tersebut akan berpengaruh terhadap kemampuan anak dalam belajar dan bersosialisasi dengan lingkungan sekitar.

\section{KESIMPULAN}

Anak berbakat adalah individu unik dengan karakteristik dan kebutuhan tersendiri yang relatif berbeda dengan anak normal pada umumnya. Munculnya karakteristik dan kebutuhan khas pada anak berbakat tersebut di samping berdampak positif terhadap berbagai aspek perkembangan, di sisi lain cenderung melahirkan berbagai permasalahan psikologis, emosional, sosial, pribadi, akademik, maupun karir pada mereka.

Seharusnya ada peraturan pemerintah yang mengatur pendidikan anak berbakat juga berakibat belum terdapatnya keseragaman di kalangan praktisi pendidikan dalam bertindak dan bersikap menghadapi anak berbakat di sekolahnya. Ketika mereka mulai peduli dan ingin memberi perhatian khusus terhadap kebutuhan pendidikan dan demi kemajuan belajar anak, saat itu juga mereka dihadapkan pada keraguan dan kebinggungan, bahkan ketakutan melanggar kebijakan. Begitu juga ketika menghadapai orang tua atau masyarakat yang menuntut sedikit saja "perhatian khusus" pada anaknya yang dianggap berbakat. 


\section{REFERENCES}

Bk, P., \& Pancasakti, U. (2015). KEBUTUHAN PSIKOLOGIS PESERTA DIDIK Hastin Budisiwi dan Sukoco KW, 1(3), 58-64.

Idrus, M. (2013). Layanan Pendidikan bagi Anak Gifted, 2(2).

Karir, D. A. N. K. (2008). Karakteristik dan kebutuhan anak berbakat dan implikasi dalam layanan bimbingan dan konseling karir, 1-17.

Larasati, G., Rachmad, A., Winarno, D., Psikologis, F., Katolik, U., \& Semarang, S. (n.d.). KELAS AKSELERASI, 58-87.

Maslow, T. A. (n.d.). Teori hirarki kebutuhan, 1-5.

Olimat, M. (2010). Gifted Students, 5, 1112-1114. https://doi.org/10.1016/j.sbspro.2010.07.244

Prastowo, A., Studi, P., Guru, P., \& Ibtidaiyah, M. (2013). PEMENUHAN KEBUTUHAN PSIKOLOGIS PESERTA DIDIK SD / MI MELALUI PEMBELAJARAN TEMATIK-TERPADU, 1-13.

Psikologi, P. S., Kedokteran, F., \& Udayana, U. (2015). Gambaran kebutuhan psikologis pada anak dengan gangguan emosi dan perilaku. 